\title{
Arsenic Accumulation in Common Vegetables from Irrigation
}

\author{
M. N. Islam, B. K. Das, and M. E. Huque* \\ Department of Chemistry, Rajshahi University, Rajshahi 6205, Bangladesh \\ Received 27 April 2012, accepted in final revised form 9 July 2012
}

\begin{abstract}
Arsenic-accumulation pattern in eight types of vegetables commonly found in Bangladesh were studied using successive irrigation/harvesting technique. The study also included to find the threshold amount of arsenic that leads to exceed the maximum permissible limit (MPL) in those vegetables and several water-soil-plant arsenic concentration models. Total arsenic concentrations were measured by Hydride Generation-Atomic Absorption Spectroscopy (HG-AAS) technique. Arsenic-accumulation decreased in the order: Arum > Arum leaf $>$ Amaranth $>$ Brinjal $>$ Radish $>$ Indian Spinach $>$ Carrot $>$ Okra. A single harvesting of 10 irrigations with water (3.0 L/irrigation) having arsenic concentrations of $\geq 0.45 \mathrm{mg} \mathrm{L}^{-1}$ to $0.071 \mathrm{~m}^{2}$ area (equivalent to $1.89 \mathrm{~kg} \mathrm{As} \mathrm{ha}^{-1}$ ) exceeded the MPL in vegetables (1 mg kg-1, wet weight). The concentration of accumulated arsenic in the vegetables increased linearly with time and exponentially with successive harvesting. Regression analyses showed that arsenic concentration in vegetables was positively correlated with that of irrigation water and soil ( $r=0.796$ for both cases).
\end{abstract}

Keywords: Arsenic; Vegetables; Irrigation; Water-soil-plant; Bangladesh.

(C) 2012 JSR Publications. ISSN: 2070-0237 (Print); 2070-0245 (Online). All rights reserved. doi: http://dx.doi.org/10.3329/jsr.v4i3.10494 J. Sci. Res. 4 (3), 675-688 (2012)

\section{Introduction}

Inorganic arsenic, As(III) and As(V), has been classified as a human carcinogen by the International Agency for Research on Cancer [1]. A study conducted by the British Geological Survey (BGS) reported that the groundwater from shallow tube-wells, a popular source of drinking water, in 61 out of 64 districts of Bangladesh was contaminated with arsenic [2]. An estimated 24 million people are directly exposed to this contamination and another 75 million are at risk [3]. Nearly 7,600 patients have been identified and a few deaths due to arsenic-related diseases have also been reported [3-6]. Evidently, Bangladesh is facing probably the largest mass poisoning in history.

The area under irrigation has been increased significantly over the last fifteen years in Bangladesh to raise food production mainly through installation of shallow tube-wells [7]. The increased use of arsenic contaminated groundwater for irrigation purpose suggests

${ }^{*}$ Corresponding author: emhuque@yahoo.com 
that consumption of the irrigated crops and vegetables could be another major exposure route of arsenic in humans in Bangladesh.

Huq and Naidu [8] reported that Arum, Amaranth and Ipomoea were good arsenic accumulators. They found the levels of arsenic in Arum and Potato up to 153 and $2.4 \mathrm{mg}$ $\mathrm{kg}^{-1}$ (dry wt.) respectively. They also reported arsenic concentration in irrigation water in affected areas ranged $0.136-0.555 \mathrm{mg} \mathrm{L}^{-1}$. Williams et al. [9] from food market-basket survey showed that arsenic accumulated in the order: Arum stolon > Brinjal > Cucumber $>$ Coriander $>$ Potato > Long-yard Bean > Radish Leaf > Giant Taro (Mankochu) $>$ Vegetable Papaya. Some data [10-11] suggested that arsenic concentration in the topsoil of Bangladesh was $83 \mathrm{mg} \mathrm{kg}^{-1}$ (wet weight), whereas that in the soil below $30 \mathrm{~cm}$ was 3-9 $\mathrm{mg} \mathrm{kg}^{-1}$ (wet weight).

In this work, the level of arsenic contamination and its accumulation pattern in eight types of vegetables commonly found in Bangladesh have been studied. The vegetables studied are: Arum (Colocasia esculenta), Radish (Raphanus sativus), Potato (Solanum tuberosum), Amaranth (Amaranthus sp.), Indian Spinach (Basella alba), Okra (Ablemoschus esculentus), Carrot (Daucas carota) and Brinjal (Solanum melongena).

To our knowledge, this is the first paper that reports on cumulative pattern of arsenicaccumulation in vegetables and soil due to successive harvesting and on the threshold amount of arsenic that leads to exceed the maximum permitted level (MPL) in vegetables. These are of special importance in formulating national guidelines. This study established several models involving arsenic concentrations in vegetables, irrigation water and cultivated soil as well as on those of vegetable plant organs. The daily human intake of arsenic from vegetables with respect to total ingested arsenic was also estimated through modeling. Based on WHO provisional tolerable weekly intake (PTWI) for inorganic arsenic [12], the vegetables were assessed for arsenic exposure that should not cause any deleterious human health effect. In the context of groundwater arsenic contamination in Bangladesh and other parts of the world, these issues were needed to be addressed seriously for ensuring safety of human health.

\section{Experimental}

\subsection{Soil processing}

The soil was collected from a field that was under an agro-ecological zone of the Ganges Fluvial Floodplain. The control soils were mixed with the commercially available inorganic fertilizers such as urea, TSP (Triple Super Phosphate) and potash $\left(\mathrm{K}_{2} \mathrm{O}\right)$ well in the N-P-K ratio of 2:1:1 along with an appropriate amount of the organic fertilizer, biodegraded cow-dung and the insecticide Furadone (Carbofuran) [13]. The soil was allowed to stand for at least 120 hours to stabilize the mix. An amount of $15.00 \pm 0.25 \mathrm{~kg}$ (wet weight) of the processed soil was poured into each labeled earthen pot with a surface area of $0.071 \mathrm{~m}^{2}$. Major physical and chemical properties of control and fertilizer fortified soils are listed in Table 1. 
Table 1. Selected physical and chemical properties of tested soils.

\begin{tabular}{lccc}
\hline \multicolumn{1}{c}{ Parameter } & Unit & Control soil & Fertilizer amended soil \\
\hline \multicolumn{1}{c}{$\mathrm{pH}$} & & 7.51 & 7.94 \\
Electrical conductivity & $\left(\mathrm{dSm}^{-1}\right)$ & 7.37 & 7.69 \\
Organic matter & $(\%)$ & 1.62 & 3.55 \\
Water content & $(\%)$ & 11.3 & 15.0 \\
Sand & $(\%)$ & 89.6 & 81.5 \\
Clay + silt & $(\%)$ & 10.4 & 18.5 \\
Total As & $\left(\mathrm{mg} \mathrm{kg}^{-1}\right)$ & 6.802 & 9.935 \\
Total P & $\left(\mathrm{mg} \mathrm{kg}^{-1}\right)$ & 27.36 & 240.8 \\
Extractable Fe & $\left(\mathrm{mg} \mathrm{kg}^{-1}\right)$ & 8.16 & 12.2 \\
\hline
\end{tabular}

${ }^{\S}$ Extracted by ammonium oxalate-oxalic acid buffer.

\subsection{Irrigation}

After seeding, the pots were watered with natural groundwater having arsenic (As) concentrations of $0.044,0.103,0.507$ and $0.903 \mathrm{mg} \mathrm{L}^{-1}$ and with model water having As concentrations of $1.00,5.00,10.00,25.00$ and $50.00 \mathrm{mg} \mathrm{L}^{-1}$. The former were collected from shallow aquifer of Rajshahi, Bangladesh through tube-wells (0.005 and 0.044 ppm from Boaliapara of Boalia Upazilla, 0.103 ppm from Nawhata of Paba Upazilla and, 0.507 and $0.903 \mathrm{ppm}$ from Kismat Kukhondi of Motiher Upazilla) without any treatment. The latter were prepared by adding the required amount of standard $\mathrm{As}_{2} \mathrm{O}_{3}$ solution to the supplied tap water of semi-deep aquifer. Since arsenic concentration in the available natural groundwater was not more than $0.903 \mathrm{mg} \mathrm{L}^{-1}$, model water was prepared for studies with higher arsenic concentrations. Groundwater having arsenic concentration of $0.005 \mathrm{mg} \mathrm{L}^{-1}$ was applied as control run. The plants of interest were watered 10 times over a period of $80-90$ days with a usage of $3.0 \mathrm{~L} /$ pot/irrigation. The average interval of irrigation was 7 days that ensured field level moisture content in soil. Successive harvesting (one harvesting corresponded to 10 irrigations) was made with the same soil.

\subsection{Sampling}

Prior to water sample analysis, the tube-wells were flushed with 2-3 tube-well volumes of groundwater (e.g., $70 \mathrm{~L}$ for tube-well having depth of $20 \mathrm{~m}$ and internal diameter of $4 \mathrm{~cm}$ ) [14-15]. The clear water samples were collected in $500 \mathrm{~mL}$ acid-washed polyethylene bottles, acidified with $69 \% \mathrm{HNO}_{3}$ to keep $\mathrm{pH}$ below 2 and stored in refrigerator at $4^{\circ} \mathrm{C}$ [16]. For plant tissue sampling, the vegetable plants were rinsed with double distilled deionized water, dried in an oven at $70^{\circ} \mathrm{C}$ for $48 \mathrm{~h}$ and ground in a ceramic mortar followed by sieving with $0.5 \mathrm{~mm}$ screen. The soils were collected from $0-6 \mathrm{~cm}$ beneath the surface layer and most distant from the root in polyethylene bags. The soils were then dried in an oven at $105^{\circ} \mathrm{C}$ for $24 \mathrm{~h}$, ground and sieved with $0.5 \mathrm{~mm}$ screen. 


\subsection{Digestion and analysis}

For determination of total arsenic concentration $\left(\mathrm{As}_{\mathrm{T}}\right)$, the irrigation water, plant tissues and soil samples were digested with $\mathrm{HNO}_{3}-\mathrm{H}_{2} \mathrm{SO}_{4}, \mathrm{HNO}_{3}-\mathrm{H}_{2} \mathrm{SO}_{4}-\mathrm{HClO}_{4}$ and $\mathrm{H}_{2} \mathrm{SO}_{4}$ $\mathrm{HClO}_{4}$ acid mixtures, respectively [16-20]. The digestates after dilution were analyzed for $\mathrm{As}_{\mathrm{T}}$ by Hydride Generation-Atomic Absorption Spectroscopy (HG-AAS) using an AAnalyst 200 (Perkin Elmer; Shelton, CT, U.S.A.) that was equipped with a Mercury/Hydride System MHS-15 (Perkin Elmer). Prior to €analysis by hydride generation, $1.5 \mathrm{~mL}$ of $37 \%$ (w/v) $\mathrm{HCl}, 1.0 \mathrm{~mL}$ of $3 \%(\mathrm{w} / \mathrm{v}) \mathrm{KI}$ (containing $3.0 \mathrm{~g} \mathrm{KI}$ and $5.0 \mathrm{~g} \mathrm{~L}(+)$-ascorbic acid in $100 \mathrm{~mL}$ water) and $5.0 \mathrm{~mL}$ of double distilled de-ionized water were added to $10.0 \mathrm{~mL}$ of the digestates and allowed to stand for 30 minutes to reduce $\mathrm{As}(\mathrm{V})$ to $\mathrm{As}(\mathrm{III})$. Other parameters were also measured for cultivated soils and groundwater.

\subsection{Quality assurance}

All glassware were treated with $10 \%(\mathrm{v} / \mathrm{v}) \mathrm{HNO}_{3}$ for $24 \mathrm{~h}$ and then rinsed three times with double distilled de-ionized water followed by drying in an oven. Arsenic analysis was carried out following the United States Environmental Protection Agency (USEPA) approved Quality Assurance/Quality Control (QA/QC) plan with a reagent blank, a duplicate and a spike for every 20 samples. The recoveries of arsenic from the environmental samples were 91-108\%. Moreover, after analyzing every 10 samples, readings of standard solutions were recorded to check the instrument. Two standard reference materials [Tomato Leaves (SRM 1573a) and Pond Sediment (NIES 2)] were digested and analyzed in five replicates for $\mathrm{As}_{\mathrm{T}}$ under the identical experimental conditions to check accuracy of the method. For tomato leaves, observed value was $0.117 \pm 0.009 \mathrm{mg} \mathrm{kg}^{-1}$ (certified value $=0.112 \pm 0.004 \mathrm{mg} \mathrm{kg}^{-1}$ ) and for pond sediment, that was $10.9 \pm 1.6 \mathrm{mg} \mathrm{kg}^{-1}$ (certified value $=12 \pm 2 \mathrm{mg} \mathrm{kg}^{-1}$ ).

\subsection{Field trails}

For field trails, the cultivation was made under natural conditions in the same field from where the soil of the pot experiments was utilized. The soil was amended with the same fertilizers in the same ratio as mentioned in 'Soil Processing' section having arsenic concentration of $9.835 \mathrm{mg} \mathrm{kg}^{-1}$ on wet weight basis. The field was divided into several 45 $\mathrm{cm} \times 45 \mathrm{~cm}$ cells; each cell was separated from another by $60 \mathrm{~cm}$ width and $30 \mathrm{~cm}$ height wall. The height of the wall prevented overflow of irrigation water and width of it supposed to prevent mixing of the water in cell through diffusion in soil. After seeding, the studied eight vegetables (Amaranth, Arum, Arum leaf, Carrot, Brinjal, Indian spinach, Okra and Radish) plants were irrigated with natural arsenic contaminated groundwater having As concentration of 0.005, 0.044, 0.103, 0.507 and $0.903 \mathrm{mg} \mathrm{L}^{-1}$ in separate cells. The plants of interest were watered 7 times over period of $80-90$ days with a usage of 12.5 
L/cell/irrigation. This makes equivalence in arsenic deposition on soil of pot. The field trails roughly showed a 1:1 correlation with pot experiment.

\subsection{Statistical analysis}

All results were expressed as an average of triplicates. The data were split into three sets for cumulative irrigation in a single harvesting, successive harvesting and water-soil-plant profile. The datasets were treated separately for analyzing basic statistical parameters and for making cross-tabulations and cross-plots. Comparisons of medians and means were made using Wilcoxon Signed Ranks test and Paired-Samples t-tests. The SPSS (release 18.0) statistical software package (SPSS Inc., Chicago, IL, 2010) and Microsoft Excel (release 12.0.4518.1014, Microsoft Corporation, 2007) were employed for the purpose. The Box-Whisker plots and 3-D graphics were constructed using the software. Mathematical models were established based on simple and multiple regression analyses. The models were cross-checked by analyzing ANOVA, $P$ value, $r$ value (Pearson correlation coefficient) and Durbin-Watson statistics. For these purposes, Curve Expert (release 1.40, Starkville, MS, 2009) and STATGRAPHICS Centurion (release 16.1) (StatPoint Technologies, Inc., Virginia, 2010) software was employed.

\section{Results and Discussions}

\section{Accumulation and toxicity of arsenic in vegetables}

The tubers of Arum, Radish, Potato and Carrot, leaves of Arum and Radish, both leaves and stems of Amaranth and Indian Spinach, and fruits of Okra and Brinjal are considered as the edible parts of the vegetables. It was observed that the concentrations of arsenic in edible parts of vegetables, [As $]_{\text {veg }}$, increased linearly with time. The Box-and-Whisker plots in Figure 1 show the distributions of arsenic in different edible plant tissues using varying arsenic content in groundwater.

The highest concentration of arsenic in fresh vegetables was found in Arum (mean 5.596 $\mathrm{mg} \mathrm{kg}^{-1}$ ), while the lowest was found in Okra (mean $0.671 \mathrm{mg} \mathrm{kg}^{-1}$, wet weight). Overall the arsenic concentrations varied from $0.346-11.559 \mathrm{mg} \mathrm{kg}^{-1}$ (wet weight) with geometric mean $0.996 \mathrm{mg} \mathrm{kg}^{-1}$ (wet weight) and median $0.912 \mathrm{mg} \mathrm{kg}^{-1}$ (wet weight). The control values for this study were $0.141-0.964 \mathrm{mg} \mathrm{kg}^{-1}$, wet weight.

It was observed that between two comparable concentrations of arsenic in natural groundwater and model water, the natural groundwater imposed more arsenic toxicity to vegetables than the model water. This is probably due to the presence of many potential ions in shallow aquifer to more extent than those in semi-deep aquifer that accelerated arsenic uptake by plants [36]. This groundwater matrix is in agreement to the general scenario of aquifer conditions of Bangladesh [2, 35].

Medians of arsenic concentrations were compared using a paired, non-parametric test (Wilcoxon Signed Ranks Test). Since the P-value is less than 0.05, this test yielded a 
statistically significant difference between control and uncontrolled arsenic concentrations of the vegetables irrigated with natural groundwater. In order to compare the mean of the vegetables for control groundwater with those for natural groundwater pairwise, PairedSamples t-tests were performed at $95 \%$ confidence interval. Since the $P$-value is less than 0.05 , there is a significant difference between the two variables for each data set.
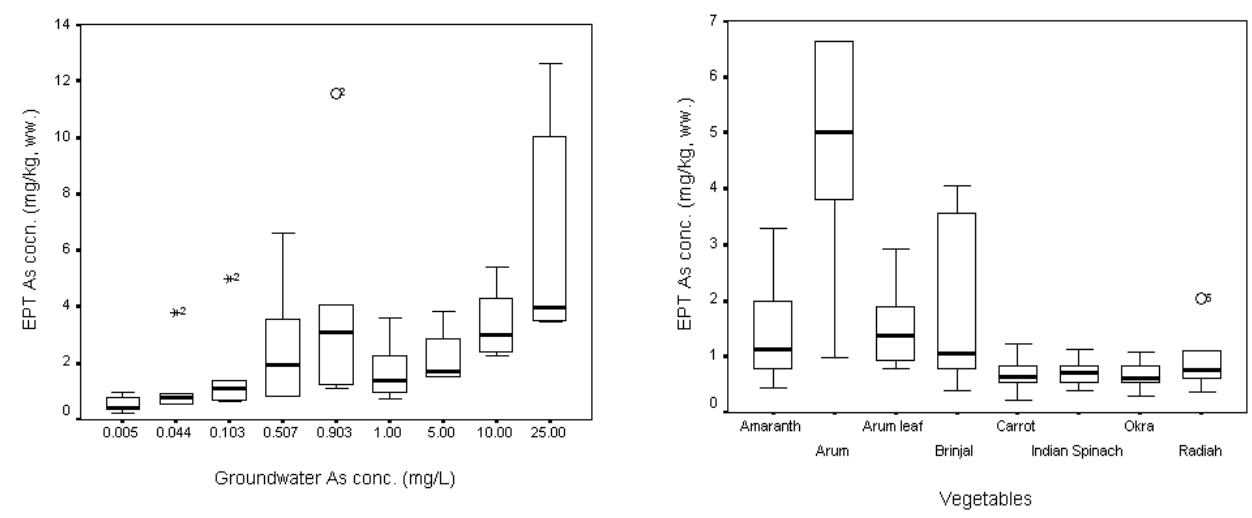

Fig. 1. Box-and-Whisker plots for arsenic distributions in vegetables for (a) different arsenic concentrations in groundwater and (b) various types of vegetables of interest. [ $(=)$ indicates median; lower and upper box boundaries $25^{\text {th }}$ and $75^{\text {th }}$ percentiles of each distribution; Whiskers as vertical lines ending in horizontal lines at the largest and smallest observed values; $\left({ }^{*}\right)$ indicates outside value and $(\mathrm{O})$ far outside value.]

The existing legislation concerning maximum permitted levels (MPL) of total arsenic in fresh vegetables varies considerably from country to country. With respect to the legislation, the MPL value is $0.5 \mathrm{mg} \mathrm{kg}^{-1}$ (wet weight) in the Slovak Republic [21] and Chile for cereal, legumes and leguminous plants, [22]; $1.0 \mathrm{mg} \mathrm{kg}^{-1}$ (wet weight) in the United Kingdom [23], Ireland [24] and Singapore [25]; $1.5 \mathrm{mg} \mathrm{kg}^{-1}$ (wet weight) in Papua New Guinea [26]. Many countries including Bangladesh have no legislation on this. We considered MPL of total arsenic in fresh vegetables in Bangladesh as $1.0 \mathrm{mg} \mathrm{kg}^{-1}$ (wet weight), based upon the maximum recommended value (1.0 mg kg-1, wet weight) of arsenic in food [27-28]. This value is intermediate in the context of international legislation. We assessed arsenic toxicity order in the vegetables based upon the MPL values. The value was obtained by plotting $[\mathrm{As}]_{\mathrm{veg}}$ against $[\mathrm{As}]_{\text {water }}$ or extrapolating the graph. It was found that arsenic toxicity in the eight vegetables decreased in the order: Arum $>$ Arum Leaf $>$ Amaranth $>$ Brinjal $>$ Radish $>$ Indian Spinach $>$ Carrot $>$ Okra .

\subsection{Cumulative effects of arsenic deposition due to successive harvesting}

Generally in any cultivated land, crops or vegetables are harvested repeatedly and consequently, groundwater arsenic is deposited in soil in cumulative manner. The cumulative effects of arsenic deposition in the four vegetables were studied for four 
harvesting periods. Each harvesting corresponds to 10 irrigations with natural groundwater with an average interval of 7 days between successive irrigations. It was generally observed that the accumulation of arsenic in the studied vegetables due to successive harvesting increased exponentially. Regression analyses showed that the fitted equation was exponential $y=a \mathrm{e}^{b x}$ (where $y$ was $[\mathrm{As}]_{\mathrm{veg}}$ in $\mathrm{mg} \mathrm{kg}^{-1}$, ww. and $x$ number of harvesting) in each case (Fig. 2).

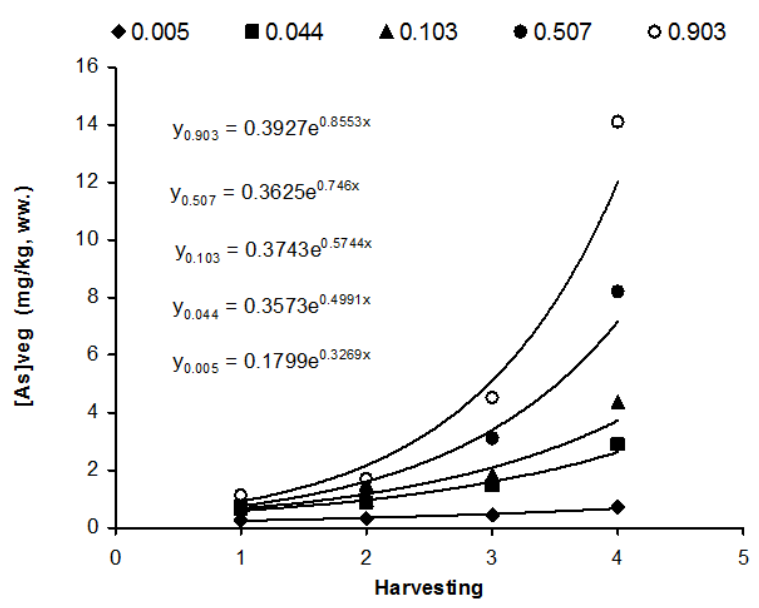

Fig. 2. Arsenic accumulation pattern in Amaranth during successive harvesting. The exponential fit equations show the relationship between vegetable arsenic concentration and number of harvesting.

Obviously, as the groundwater arsenic concentration increases, the slope of the curve is also increased. How much additional arsenic is added to the studied vegetables from one harvesting to another is represented in Table 2. The following Table reveals that the overall ratio of average increment of arsenic in the vegetables from $1^{\text {st }}$ to $2^{\text {nd }}, 2^{\text {nd }}$ to $3^{\text {rd }}$ and $3^{\text {rd }}$ to $4^{\text {th }}$ harvesting is $1: 3: 8$. This supports arsenic deposition in vegetables in exponential manner for successive harvesting.

\subsection{Threshold concentration of arsenic in irrigation water and threshold number of harvesting}

The critical concentration of arsenic in irrigation water beyond which on application in a single harvesting might cause arsenic pollution in vegetables, i.e., exceed MPL of total arsenic in fresh vegetables (1.0 mg kg-1, wet weight), has been termed as 'Threshold Concentration of Arsenic in Irrigation Water', [As $]_{\text {threshold. }}$ This parameter is important to understand the input (amount) of arsenic from irrigation water to a specific area of land causing arsenic toxicity in vegetables. It was estimated (Table 3) from $[\text { As }]_{\text {veg }}$ vs $[\text { As }]_{\text {water }}$ plots or from their extrapolation. Evidently, the vegetables, except Arum and its leaf, would become arsenic poisoned if $0.35-3.24 \mathrm{~kg}$ of arsenic is applied per hectare of land 
through irrigation with groundwater of shallow aquifer, provided that soil background arsenic concentration is $6.802 \mathrm{mg} \mathrm{kg}^{-1}$ (wet weight).

Table 2. Increment of arsenic concentration due to successive harvesting. [The values are averaged over all eight vegetables.]

\begin{tabular}{ccccc}
\hline $\begin{array}{c}{[\mathrm{As}]_{\text {water }}} \\
\left.(\mathrm{mg} \mathrm{L})^{-1}\right)\end{array}$ & $\begin{array}{r}\text { Added As in single } \\
\text { harvesting }\left(\mathrm{kg} \mathrm{ha}^{-1}\right)\end{array}$ & \multicolumn{2}{c}{$\begin{array}{c}\text { Average increment in }[\mathrm{As}]_{\text {veg }} \\
\text { for successive harvesting }\left(\mathrm{mg} \mathrm{kg}^{-1}\right)^{\dagger, ~ \S ~}\end{array}$} \\
\cline { 3 - 5 } & 0.02 & $0.037(0.393)$ & $0.071(0.791)$ & $0.142(1.583)$ \\
\hline 0.005 & 0.19 & $0.107(1.077)$ & $0.272(3.239)$ & $0.557(6.039)$ \\
0.044 & 0.44 & $0.151(1.376)$ & $0.395(3.669)$ & $1.134(11.387)$ \\
0.103 & 2.14 & $0.250(3.307)$ & $0.891(10.687)$ & $2.490(21.749)$ \\
0.507 & 3.82 & $0.432(3.708)$ & $1.237(13.901)$ & $5.825(47.208)$ \\
0.903 & to $2^{\text {nd }}$ & $3^{\text {rd }}$ & to $4^{\text {th }}$ \\
\hline
\end{tabular}

${ }^{\dagger}$ The concentrations within first bracket correspond to dry weight, while the other numbers to wet weight.

$\S$ Each value corresponds to an average of all the studied vegetables.

Table 3. Threshold concentrations of arsenic in irrigation water from shallow aquifer.

\begin{tabular}{lcc}
\hline Vegetables & $\begin{array}{c}{[\text { As }]_{\text {threshold }}} \\
\left(\mathrm{mg} \mathrm{L}^{-1}\right)\end{array}$ & $\begin{array}{c}\text { Added arsenic } \\
\left(\mathrm{kg} \mathrm{ha}^{-1}\right)\end{array}$ \\
\hline Amaranth & 0.084 & 0.35 \\
Arum leaf & 0.009 & 0.04 \\
Carrot & 0.717 & 3.03 \\
Brinjal & 0.133 & 0.56 \\
Indian spinach & 0.656 & 2.77 \\
Okra & 0.767 & 3.24 \\
Radish & 0.329 & 1.39 \\
Average $^{\mathrm{a}}$ & 0.448 & 1.89 \\
\hline
\end{tabular}

${ }^{\mathrm{a}}$ Except Arum leaf.

The minimum number of harvesting that corresponds to exceed MPL of arsenic in fresh vegetables is treated as 'Threshold Number of Irrigation'. This parameter helps to understand arsenic toxicity in vegetables with respect to harvesting that irrigated with different groundwater arsenic concentrations (Fig. 3). Generally, if [As] $]_{\text {soil }}$ is $6.802 \mathrm{mg}$ $\mathrm{kg}^{-1}$ (wet weight), 2 harvesting with water having arsenic concentration of 0.903 or 0.507 
$\mathrm{mg} \mathrm{L}^{-1}$, or 3 harvesting with that of $0.103 \mathrm{mg} \mathrm{L}^{-1}$, or 5 harvesting with $0.044 \mathrm{mg} \mathrm{L}^{-1}$, or 14 harvesting with $0.005 \mathrm{mg} \mathrm{L}^{-1}$ will exceed MPL value of total arsenic in the vegetables.

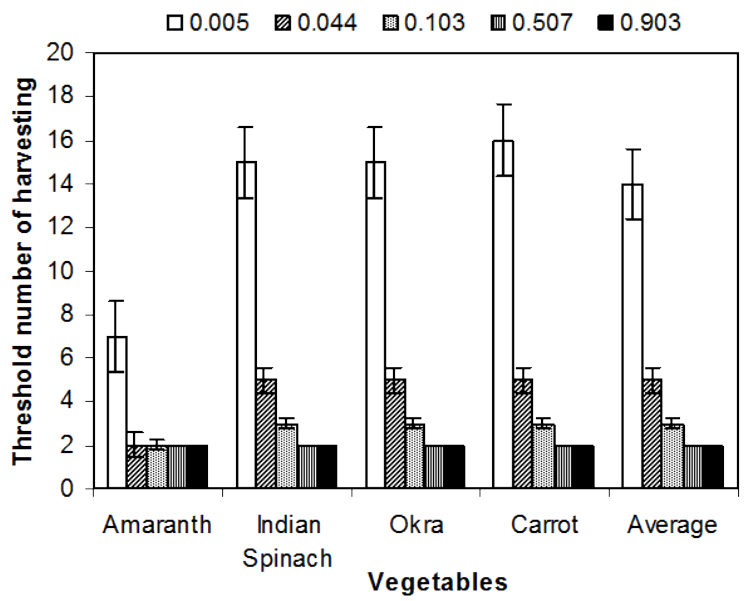

Fig. 3. Threshold number of harvesting for irrigation with natural groundwater. The groundwater arsenic concentrations in $\mathrm{mg} \mathrm{L}^{-1}$ are shown on the top of the plot, and the vertical lines represent standard errors of mean values.

\subsection{Water-soil-plant arsenic concentration relationship}

Linear regression equations and Pearson correlation coefficients (r) were calculated for total arsenic concentration, $A \mathrm{~s}_{\mathrm{T}}$. The regression equations of the fitted model were either in the form of $y=a x_{1}+b x_{2}+c$ (where $y, x_{1}$ and $x_{2}$ were $\mathrm{As}_{\mathrm{T}}\left(\mathrm{mg} \mathrm{kg}^{-1}\right.$, wet weight) in leaf/fruit, root and stem respectively) or $y=a x+b$ (where $y$ was $\mathrm{As}_{\mathrm{T}}$ ( $\mathrm{mg} \mathrm{kg}^{-1}$, wet weight) in stem or leaf/fruit and $x$ that in root or stem) (Table 5). In this study surface soil of depth 0-6 cm were considered to establish the water-soil-plant arsenic relationship.

The bio-availability of arsenic, i.e., transfer of arsenic from soil to plant organs was assessed with six vegetable plants. The ratios of arsenic concentrations of soils to plant organs were analyzed to estimate the bio-availability. The average soil/plant arsenic ratio was found to be lower (4.704) for root followed by stems (10.466) and leaves (29.505). Comparison of these data with those of the references [29-30] shows that the soil/vegetation arsenic ratio is lower in this study. This indicates a comparatively higher intake of arsenic in the studied plants, reflecting that the vegetables are good accumulators of arsenic.

The regression equations of the fitted model for correlations of $\mathrm{As}_{\mathrm{T}}$ in both natural and model irrigation water with those in vegetables are shown in Table 4. The observed vegetables-irrigation water linear relationship (Fig. 4) is important to get an indication of arsenic-accumulation in vegetables from hydro-geological data of groundwater. For this, proper calibration is required. The relationship between $A s_{\mathrm{T}}$ of soil and irrigation water or vegetables was also linear (Table 5). 


\section{Arsenic Accumulation}

Since the $P$ values in the ANOVA Tables are less than 0.01 , the above relationships are statistically significant at $99 \%$ confidence level. The $r$ (correlation coefficient) values indicate a fairly strong relationship amongst the variables. Since the Durbin-Watson values are greater than 1.4 , there are no serious autocorrelation in the residuals.

Table 5. Regressions between total arsenic concentrations of plant tissue, soil and water.

\begin{tabular}{|c|c|c|c|}
\hline Factors & Regression equations & $r$ value & $P$ value \\
\hline \multicolumn{4}{|l|}{ (a) For root, stem and leaf/fruit: } \\
\hline Stem and soot $(\mathrm{n}=30)$ & $y=0.362 x+0.3930 .957$ & & $<0.001$ \\
\hline Leaf/fruit and stem $(n=30)$ & $y=0.584 x-0.134$ & 0.804 & $<0.001$ \\
\hline Leaf/fruit, root and stem $(n=30)$ & $y=0.391 x_{1}-0.406 x_{2}-0.780$ & $0.890,-0.804$ & $<0.001$ \\
\hline \multicolumn{4}{|l|}{ (b) For plant tissue, soil and water: } \\
\hline Vegetables and soil $(n=40)$ & $y=0.051 x+0.376$ & 0.785 & $<0.001$ \\
\hline Root and soil $(\mathrm{n}=30)$ & $y=0.175 x+2.314$ & 0.874 & $<0.001$ \\
\hline Natural water and vegetables $(n=38)$ & $y=1.068 x+0.481$ & 0.776 & $<0.001$ \\
\hline Model water and vegetables $(n=22)$ & $y=0.138 x+0.592$ & 0.962 & $<0.001$ \\
\hline Groundwater and vegetables $(n=40)$ & $y=0.946 x+0.031$ & 0.784 & $<0.001$ \\
\hline Vegetables, water and soil $(n=55)$ & $y=0.472 x_{1}+0.026 x_{2}+0.113$ & 0.796, 0.796 & $<0.001$ \\
\hline Root, water and soil $(n=30)$ & $y=0.995 x_{1}+0.122 x_{2}+1.868$ & $0.870,0.874$ & $<0.001$ \\
\hline \multicolumn{4}{|l|}{ (c) For soil and groundwater: } \\
\hline Soil and groundwater $(n=10)$ & $y=18.453 x-5.302$ & 0.991 & $<0.001$ \\
\hline
\end{tabular}

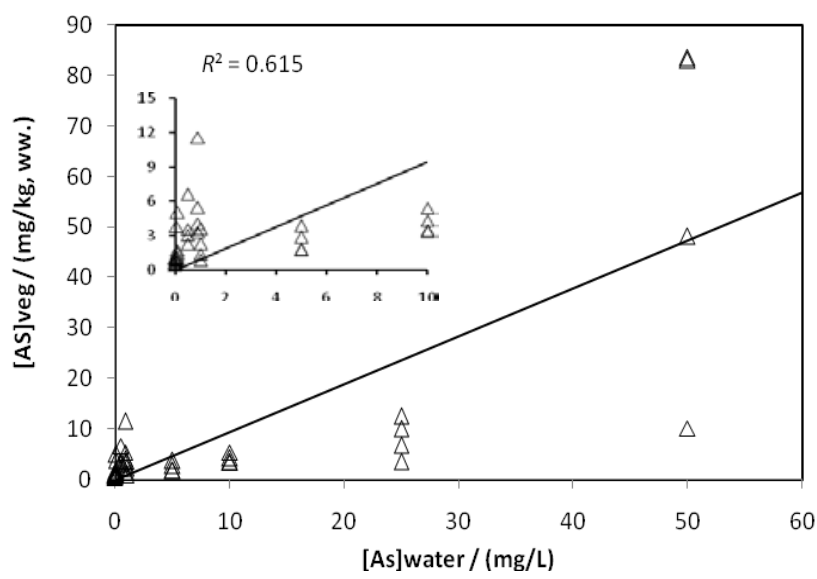

Fig. 4. Relationship amongst arsenic concentrations of vegetables and irrigation water ( $30.0 \mathrm{~L}$ of irrigation water were applied to $0.071 \mathrm{~m}^{2}$ of surface soil within $80-90$ days). Inset represents the enlarged figure for lower values.) 


\subsection{Human health implications}

The World Health Organization (WHO) has set $15 \mu \mathrm{g}$ of arsenic per kg of body weight as a limit of provisional tolerable weekly intake (PTWI) for inorganic arsenic [12]. Assuming a body weight of $70 \mathrm{~kg}$, the PTWI is $1050 \mu \mathrm{g}$. Although it is recommended that each person should consume $200 \mathrm{~g}$ of fresh vegetables per day [31], the Bangladeshi consumes $130 \mathrm{~g}$ of it per day [32]. Assuming that 95\% of total arsenic is inorganic [33$34]$, the estimated one-week intake of inorganic arsenic through consumption of the vegetables is represented in Table 6.

Table 6. Estimated intake of inorganic arsenic through consumption of the vegetables over a week period by an adult.

\begin{tabular}{lcccccccc}
\hline \begin{tabular}{c} 
Irrigation water $\begin{array}{c}\text { Total intake of inorganic arsenic } \\
\text { As conc. } \\
\left.\text { (mg L }{ }^{-1}\right)\end{array}$ \\
\cline { 2 - 9 }
\end{tabular} & Amaranth week $\left.{ }^{-1}\right)$ & Arum & Arum leaf & Brinjal & Carrot & $\begin{array}{c}\text { Indian } \\
\text { spinach }\end{array}$ & Okra & Radish \\
\hline 0.005 & 583.9 & 1318.0 & 1041.4 & 510.7 & 283.3 & 524.0 & 384.4 & 481.5 \\
& $(379.5)$ & $(856.7)$ & $(676.9)$ & $(332.0)$ & $(184.1)$ & $(340.6)$ & $(249.8)$ & $(312.9)$ \\
0.044 & 1044.1 & 5056.7 & 1250.2 & 1054.7 & 731.5 & 727.5 & 723.5 & 1010.8 \\
& $(678.6)$ & $(3286.8)$ & $(812.6)$ & $(685.5)$ & $(475.5)$ & $(472.9)$ & $(470.3)$ & $(657.0)$ \\
0.103 & 1493.6 & 6658.0 & 1842.1 & 1409.8 & 852.5 & 952.3 & 819.3 & 818.0 \\
& $(970.8)$ & $(4327.7)$ & $(1197.3)$ & $(916.4)$ & $(554.1)$ & $(619.0)$ & $(532.5)$ & $(531.7)$ \\
0.507 & 2650.7 & 8807.3 & 2501.7 & 4741.5 & 1095.9 & 1111.9 & 1110.6 & 1463.0 \\
& $(1722.9)$ & $(5724.7)$ & $(1626.1)$ & $(3081.9)$ & $(712.3)$ & $(722.7)$ & $(721.9)$ & $(951.0)$ \\
0.903 & 4361.1 & 15373.5 & 3886.3 & 5381.2 & 1630.6 & 1494.9 & 1425.8 & 2701.2 \\
& $(2834.7)$ & $(9992.8)$ & $(2526.1)$ & $(3497.8)$ & $(1059.9)$ & $(971.7)$ & $(926.7)$ & $(1755.8)$ \\
\hline
\end{tabular}

${ }^{\mathrm{a}}$ Values within first bracket are for Bangladeshi consumption, while the others for recommended consumption.

The consumptions of Okra, Indian Spinach and Carrot, irrigated with water of shallow aquifer of arsenic concentration up to $0.9 \mathrm{mg} \mathrm{L}^{-1}$, for Bangladeshi population, in principle, do not expose deleterious health effect. The consumptions of Radish, Brinjal and Amaranth, grown with irrigation water having arsenic concentration of about $0.2 \mathrm{mg} \mathrm{L}^{-1}$, in general, are considered to be safe. But caution must be exercised while ingesting Arum that has arsenic hyper-accumulating tendency. For safe consumption of Okra, Indian Spinach and Carrot at recommended level $\left(0.2 \mathrm{~kg} \mathrm{day}^{-1}\right.$, ww. $)$, the $[\mathrm{As}]_{\text {water }}$ should not exceed $0.4 \mathrm{mg} \mathrm{L}^{-1}$. For other cases the $[\text { As }]_{\text {water }}$ value is less than $0.2 \mathrm{mg} \mathrm{L}^{-1}$. For actual exposure assessment, it is urgent to gather sufficient data on arsenic speciation in specific vegetables, arsenic content in cooked vegetables and bioconversion factor. 


\section{Conclusion}

The study reveals that when the soil, having background arsenic concentration of 9.835 $\mathrm{mg} \mathrm{kg}^{-1}$ (wet weight), is irrigated with natural arsenic-contaminated groundwater ( 0.044 $0.903 \mathrm{mg} \mathrm{L}^{-1}$ ), arsenic contents in the fresh vegetables become $0.346-11.559 \mathrm{mg} \mathrm{kg}^{-1}$ (control values $0.141-0.964 \mathrm{mg} \mathrm{kg}^{-1}$ ). Arsenic-accumulation is decreased in the order: Arum $>$ Arum leaf $>$ Amaranth $>$ Brinjal $>$ Radish $>$ Indian spinach $>$ Carrot $>$ Okra. A single harvesting of 10 irrigations with water (3.0 L/irrigation) having arsenic concentrations of $\geq 0.45 \mathrm{mg} \mathrm{L}^{-1}$ to $0.071 \mathrm{~m}^{2}$ area (equivalent to $1.89 \mathrm{~kg}^{\mathrm{As} \mathrm{ha}}{ }^{-1}$ ) exceed the MPL in vegetables ( $1 \mathrm{mg} \mathrm{kg}^{-1}$, ww.). The concentration of accumulated arsenic in the vegetables increased linearly with time and exponentially with successive harvesting. It is observed that arsenic concentration in vegetables is positively correlated with that of irrigation water and soil ( $r=0.796$ for both cases). The lower values of soil/vegetation arsenic ratio reflect that the vegetables are good accumulators of arsenic. The concentrations of arsenic in roots, stems and leaves or fruits are found to decrease in geometric proportions. According to the World Health Organization (WHO) provisional tolerable weekly intake (PTWI) of inorganic arsenic, the consumptions of Okra, Indian Spinach and Carrot with an average intake rate of $0.13 \mathrm{~kg} \mathrm{day}^{-1}$ (ww.) is safe, but the consumption of Arum at the same rate might be of health risk.

\section{Acknowledgement}

The research was partially funded by the University of Rajshahi, Bangladesh. We thank Mr. Jan-Willem Rosenboom (Project Officer, Water \& Environmental Sanitation Sector, UNICEF-Bangladesh) and Mr. Mahabubur Rahman (Scientific Officer, Regional Laboratory, Soil Resource Development Institute, Rajshahi, Bangladesh) for literature and laboratory supports. We also acknowledge Dr. Abdullah Al Mahmud (Post-doctoral Researcher, The University of California, Davis, USA) for his valuable assistance.

\section{References}

1. International Agency for Research on Cancer, In: IARC Monographs on the Evaluation of Carcinogenic Risks to Humans, France, Lyon, 1-42, suppl 7 (1987).

2. BGS, Technical Report WC/00/19, British Geological Survey, UK, 2: 77(2001).

3. Engconsult Limited, Toronto, Canada, 2002. http://www.eng-consult.com/arsenic/arsstat.html [accessed 22 June 2009].

4. SOES-DCH, School of Environmental Studies, Jadavpur University, Calcutta and Dhaka Community Hospital, Dhaka, 2000. http://www.eng-consult.com/arsenic/article/BANGLAREPORT.pdf

5. M. A. Fazal, T. Kawachi, and E. Ichion, Water International 26, 370 (2001). http://dx.doi.org/10.1080/02508060108686929

6. New Age, Op-Ed page, Dhaka, Bangladesh, September 14, 2005. http://www.newagebd.com/2005/sep/14/oped.html

7. Government of Bangladesh. 2010 Yearbook of Agricultural Statistics of Bangladesh (Bangladesh Bureau of Statistics, 2010). 
8. S. M. I. Huq and R. Naidu, Arsenic in Groundwater and Contamination of the F Chain: Bangladesh Scenario, Bundschuh et al. (ed) (Taylor \& Francis Group, London, 2005).

9. P. N. Williams, M. R. Islam, E. E. Adomako, A. Raab, S. A. Hossain, Y. G. Zhu, J. Feldmann, and A. A. Meharg, Environ. Sci. Technol. 40, 4903 (2006). http://dx.doi.org/10.1021/es060222i

10. S. M. Ullah, Abstracts: International Conference on Arsenic Pollution of Groundwater in Bangladesh: Causes, Effects and Remedies, (Dhaka Community Hospital, Dhaka, Bangladesh, 8-12 February 1998), p 133.

11. M. B. Alam, and M. A. Sattar, Water Sci. Technol. 42, 185 (2000).

12. World Health Organization, Geneva; WHO Food Additives Series No. 24; 1989.

13. M. S. Amin, Environmental Science: Indications of Fertilizer Application, 1st ed. (Bangla Academy, Dhaka, Bangladesh, 1998), p. 200.

14. BAMWSP. Bangladesh Arsenic Mitigation Water Supply Project, Government of Bangladesh, 1999.

15. M. Berg, H. C. Tran, T. C. Nguyen, H. V. Pham, R. Schertenleib, and W. Giger, Environ. Sci. Technol. 35, 2621 (2001). http://dx.doi.org/10.1021/es010027y

16. APHA, Standard Methods for the Examination of Water and Wastewater, 19th ed. (United Book Press, Inc., Baltimore, Maryland, American Public Health Association, 1995).

17. M. L. Jackson, Soil Chemical Analysis, (Prentice - Hall, Inc., New Jersey, 1958), p. 326.

18. H. Sakamoto, Y. Susa, H. Ishiyama, T. Tomiyasu, and K. Anazawa, Analytical Sci. 17, 1067 (2001). http://dx.doi.org/10.2116/analsci.17.1067

19. P. R. Hesse, A Textbook of Soil Chemical Analysis (CBS Publishers and Distributor, Delhi, India 1994).

20. Perkin-Elmer, MHS 15 Mercury Hydride System User’s Guide (Perkin-Elmer, Inc., Connecticut, USA, 2011).

21. Ministry of Agriculture and Ministry of Health, Slovak Republic foodstuffs code governing contaminants in foodstuffs. Decree No. 15116/2005-SL, Slovak Republic, 2005.

22. Diario Oficial de la Republica de Chile, Martes 13 de mayo de 1997, Decreto 977, Reglamento Sanitario de los Alimentos (RSA), Titulo IV, De los contaminantes, Párrafo I, de los metales pesados, Artículo 160, Arsénico.

23. MAFF, Ministry of Agriculture, Fisheries and Food, Department of Health, UK. Food Safety Information Bulletin No. 87, 1997.

24. Food Safety Authority, Food Safety Authority of Ireland Act, 1998. The Stationery Office, Government of Ireland, Dublin, 2000.

25. AVA, Sale of Food Act, Agri-Food \& Veterinary Authority, Government of Singapore, 13 September 2006.

26. Office of Legislative Counsel, Papua New Guinea Consolidated Legislation, Papua New Guinea, 15 September 2009.

27. S. A. Ahmad, Arsenic: Water Contamination and Health Hazards, 1st ed. (Udayan Press, Rajshahi, Bangladesh, 2000), p. 48.

28. NIPSOM, Interim report on arsenic, National Institute of Preventive and Social Medicine, Dhaka, Bangladesh, 1994.

29. A. Milton, and M. Johnson, Chemosphere 39, 765 (1999). http://dx.doi.org/10.1016/S0045-6535(99)00012-0

30. G. A. Pascoe, R. J. Blanchet, and G. Linder, Arch. Environ. Contam. Toxicol. 27, 44 (1994). http://dx.doi.org/10.1007/BF00203886

31. R. A. Schoof, L. J. Yost, J. Eickhoff, E. A. Crecelius, D. W. Cragin, D. M. Meacher, and D. B. Menzel, Food Chem. Toxicol. 37, 839 (1999). http://dx.doi.org/10.1016/S0278-6915(99)00073-3

32. BBS. Household Income and ExpenditureS-2010. Bangladesh Bureau of Statistics, Ministry of Planning, Government of Bangladesh, Dhaka, 2011.

33. C. Abernathy, Exposure and health effects, UN Synthesis Report on Arsenic (2001) p. 3-73. 
34. U. K. Chowdhury, M. M. Rahman, B. K. Mondal, K. Paul, D. Lodh, B. K. Biswas, G. K. Basu, C. R. Chanda,K. C. Saha, S. C. Mukherjee, S. Roy, R. Das, I. Kaies, A. K. Barua, S. K. Palit, Q. Quamruzzaman, and D. Chakraborti, Environ. Sci. 8, 393 (2001).

35. S. M. N. Islam, S. H. Rahman, D. A. Chowdhury, M. M. Rahman, and S. M. Tareq, J. Sci. Res. 4, 65 (2012). http://dx.doi.org/10.3329/jsr.v4i1.7820

36. M. R. Shaibur, N. Kitajima, S. M. I. Huq, and S. Kawai, Soil Sci. Plant Nutrition 55, 739 (2009). http://dx.doi.org/10.1111/j.1747-0765.2009.00414.x 